Jurnal Teknologi Pertanian Vol. 19 No. 2 [Agustus 2018] 95-106

Penggunaan Minyak Sawit Merah dalam Pembuatan Sambal [Hasibuan dkk]

\title{
PENGGUNAAN MINYAK SAWIT MERAH DALAM PEMBUATAN SAMBAL CABAI MERAH TUMIS
}

\section{The Utilization of Red Palm Oil in Preparation of Stir-Fry Red Chilli Sauce}

\author{
Hasrul Abdi Hasibuan ${ }^{1 *}$, Rendi Meilano² \\ ${ }^{1}$ Pusat Penelitian Kelapa Sawit \\ Jl. Brigjend Katamso No. 51 Medan \\ ${ }^{2}$ Program Studi Kimia - Fakultas Matematika dan Ilmu Pengetahuan Alam - Universitas Negeri Medan \\ Jl. Willem Iskandar Ps. V Medan Estate, Deli Serdang 20222 \\ *Penulis Korespondensi: email: hasibuan_abdi@yahoo.com
}

\begin{abstract}
ABSTRAK
Sambal cabai merah tumis dibuat dengan cara menumis cabai mentah giling menggunakan minyak goreng. Nutrisi sambal cabai merah ditingkatkan menggunakan minyak sawit merah (MSM) sebagai media penumisan karena mengandung fitonutrien berupa karoten (pro-vitamin A) dan tokoferol \& tokotrienol (vitamin E). Penelitian ini mengkaji pengaruh rasio cabai dan minyak, pengaruh penambahan garam dan gula, pengaruh suhu dan waktu pemasakan, pengaruh jenis minyak, uji ketahanan simpan dan uji penerimaan dalam pembuatan sambal cabai merah menggunakan MSM dan fraksi oleinnya (MSMOL). Parameter mutu minyak yang dianalisis meliputi komposisi asam lemak, kadar air, kadar karoten, bilangan peroksida, dan kadar karoten. Analisa tingkat kesukaan produk sambal meliputi kenampakan warna, tekstur, aroma, dan rasa. Penerimaan terhadap kesukaan sambal tertinggi yaitu pada rasio cabai dan MSM atau MSMOL adalah 50:40 (g/g), rasio garam dan gula adalah $2 \%$ dan $4 \%$ terhadap berat cabai. Suhu dan waktu pemasakan mempengaruhi kadar air dan karoten sambal. Semakin tinggi suhu, menurunkan kadar air, namun meningkatkan kadar karoten pada sambal (kecuali pada suhu $>150^{\circ} \mathrm{C}$, kadar karoten menurun). Pemasakan sambal dengan mencampurkan cabai dengan MSM, kemudian dipanaskan secara bersamaan pada suhu $150{ }^{\circ} \mathrm{C}$ selama 5 menit. Tingkat penerimaan sambal cabai merah menggunakan MSM atau MSMOL relatif sama dengan minyak goreng komersial (MGK) sebagai kontrol. Sambal cabai merah menggunakan MSMOL lebih tahan lama dibandingkan MGK dan MSM ditinjau dari mutunya meliputi kadar asam lemak bebas, bilangan peroksida, dan kadar karoten. Waktu yang baik untuk menyimpan sambal cabai dengan MSMOL adalah 2 minggu pada $20-24^{\circ} \mathrm{C}$ atau 1 minggu pada $28-30{ }^{\circ} \mathrm{C}$
\end{abstract}

Kata kunci : Cabai, Sambal, Minyak Sawit Merah, Karoten

\begin{abstract}
Red chili sauce stir-frying made from chili that has been milled and fry using cooking oil. Red chili sauce nutrients can be enhanced by using red palm oil (RPO) as a medium of frying because contains phytonutrient like carotenes and tocopherols $\mathcal{E}$ tocotrienols (vitamin $E$ ). This research conducted to examine ratio of chilli and oil, temperature and cooking time, oil types, the resistance during storage and the acceptance of red chili sauce using RPO and its olein fraction (RPOlein). Oil quality analyzed were fatty acid content, moisture content, carotene content, peroxide value and carotene content. Analysis of the acceptance of red chili sauce were color, texture, aroma, and taste. The highest acceptance of red chili sauce at the ratio of chili and RPO or RPOlein was 50:40 g/g and the ratio of salt and sugar was $2 \%$ and $4 \%$ from weight of sauce. The temperature and the cooking time affecting the water and carotene content of the sauce. The higher temperature tends to decrease the water content, but increase the carotene content in the sauce (except at $>150^{\circ} \mathrm{C}$, decreased carotene levels). Best processing achieved by mixing chili with $R P O$, heated at $150^{\circ} \mathrm{C}$ for 5 minutes. The acceptance of red chili sauce using RPO or RPO relatively same with commercial cooking oil as a control. Red chili sauce using RPO relatively durable than commercial cooking oil and RPO in terms of quality of free fatty acid, peroxide value, and carotene content. Best time to save chili sauce with RPO is 2 weeks at $20-24^{\circ} \mathrm{C}$ or 1 week at $28-30{ }^{\circ} \mathrm{C}$
\end{abstract}

Keywords : Carotene, Chili, Red Palm Oil, Sauce 
Jurnal Teknologi Pertanian Vol. 19 No. 2 [Agustus 2018] 95-106

Penggunaan Minyak Sawit Merah dalam Pembuatan Sambal [Hasibuan dkk]

\section{PENDAHULUAN}

Cabai merah (Capsicum annuum L) merupakan salah satu komoditas bahan kebutuhan pangan maupun sebagai bumbu dapur yang dikonsumsi sehari-hari di rumah tangga tanpa memperhatikan tingkat sosial (Samadi, 2007; Alex, 2012). Sambal cabai juga telah diproduksi dalam jumlah besar pada skala industri (Hin et al., 2008; Gamonpilas et al., 2011; Iqbal et al., 2011; Iqbal et al., 2017). Cabai juga telah didiversifikasi menjadi penyedap untuk berbagai produk makanan olahan seperti mie instan dan sambal dengan nilai tambah produk yang signifikan (Farid dan Subekti, 2012). Cabai merah mengandung banyak kandungan gizi meliputi air (90\%), energi (32 kkal), protein $(0.5 \mathrm{~g})$, lemak $(0.3 \mathrm{~g})$, karbohidrat (7.8 g), serat (1.6 g), abu (0.5 g), kalsium (29.0 $\mathrm{mg})$, fosfor $(45 \mathrm{mg})$, besi $(0.5 \mathrm{mg})$, vitamin A (470 IU), vitamin C (18 mg), tiamin (0.05 $\mathrm{mg})$, riboflavin $(0.06 \mathrm{mg})$, niasin $(0.9 \mathrm{mg})$ dan asam askorbat $(18.0 \mathrm{mg})$ (Ashari, 2006; Nimrotham et al., 2017; Calzada et al., 2018).

Umumnya cabai dibuat untuk sambal yang dikenal sebagai penggugah dan penambah selera makan di rumah tangga yang sebelumnya digiling atau disebut sebagai cabai giling yang digunakan sebagai bumbu inti berbagai masakan seperti rendang, gulai, sambal goreng, dan bumbu jenis masakan lainnya (Suyanti, 2009; Farkas dan Cs Mohácsi-Farkas, 2014; Kim et al., 2016; Kim et al., 2018). Sambal cabai biasanya dibuat dengan penambahan bahan lain seperti garam (Purawisastra dan Yuniati, 2010), gula (Hin et al., 2008), terasi (Sarina et al., 2010), tomat, bawang, dan lainnya. Pada skala industri, biasanya sambal cabai dibuat dengan mencampurkan tomat dan gula sebagai pemanis (Hin et al., 2008). Sambal dibedakan menjadi dua yaitu sambal masak (yang digoreng atau ditumis) dan sambal mentah. Sambal cabai goreng sering digunakan untuk campuran bahan utama seperti ikan, daging, telur, singkong, dan lain-lain.

Pembuatan sambal cabai merah tumis biasanya menggunakan minyak goreng yang dipanaskan. Namun demikian, peningkatan nutrisi sambal cabai merah tumis dapat dilakukan dengan menggunakan minyak sawit merah (MSM) pada saat menggoreng atau menumis. MSM merupakan minyak sawit kaya karoten (provitamin A), tokoferol serta tokotrienol (vitamin E) (Ayeleso et al., 2012; Hasibuan dan Siahaan, 2013). MSM mengandung 15-300 kali retinol ekuivalen dibandingkan dengan wortel, sayuran dan tomat (Hasibuan dan Siahaan, 2013). Pengaruh kombinasi antara karoten, tokoperol, tokotrienol dan $50 \%$ asam lemak tidak jenuh memberikan stabilitas oksidasi MSM lebih tinggi dibandingkan dengan minyak nabati lainnya (Ayeleso et al., 2012). MSM dapat digunakan sebagai pangan fungsional, karena MSM berperan sebagai carrier provitamin A dan vitamin E. MSM dapat digunakan untuk mengurangi dan mencegah kekurangan vitamin A (Rice and Burns, 2010; Adewuyi et al., 2014; Rao, 2000; Cassiday, 2017). Perdani et al. (2016) menambahkan bahwa konsumsi minyak sawit yang mengandung karoten tinggi dapat meningkatkan jumlah retinol plasma dalam darah dan penurunan tingkat aktivitas enzim Aspartat Transaminase (AST), Alanin Transaminase (ALT) dan enzim Alkaline Phospatase (ALP).

MSM sebagai media penggorengan dapat digunakan namun suhu sebaiknya tidak lebih dari $150{ }^{\circ} \mathrm{C}$ karena senyawa karoten mudah terdegradasi selama pemanasan (Hasibuan et al., 2013; Masani et al., 2018; Ribeiro et al., 2018; Ricaurte et al., 2018). Oleh karena itu, MSM cocok sebagai media penggorengan untuk menumis sayur, sambal, ikan, dan lain-lain. Sambal cabai merah yang dibuat menggunakan MSM dan fraksi oleinnya (MSMOL) dapat dilakukan dengan mengkaji pengaruh rasio cabai dan minyak, pengaruh penambahan garam dan gula, pengaruh suhu dan waktu pemasakan, pengaruh jenis minyak, uji ketahanan simpan dan uji penerimaannya. Pemanfaatan MSM atau MSMOL diharapkan dapat meningkatkan nilai nutrisi sambal cabai sehingga bermanfaat bagi konsumen.

\section{BAHAN DAN METODE}

\section{Bahan}

Bahan yang digunakan adalah cabai merah giling yang telah diuapkan airnya, minyak goreng komersial (MGK), garam dan gula diperoleh dari pasar tradisional di kota Medan. Minyak sawit merah (MSM) dan minyak sawit merah fraksi olein (MSMOL) diperoleh dari Science Techno House di Pusat Penelitian Kelapa Sawit, Medan. Bahan 
kimia seperti natrium hidroksida, heksan, isooktan, kalium hidroksida, phenolphthalein masing-masing pro analysis, natrium hidroksida dan ethanol teknis diperoleh dari E. Merck di Medan.

Alat

Peralatan yang digunakan adalah kromatografi gas GC 2010 merk Shimadzu dan pektrofotometer UV-VIS merk Shimadzu.

\section{Metode}

\section{Karakterisasi Minyak}

Minyak yang digunakan dikarakterisasi meliputi kadar asam lemak bebas (ALB), kadar air, bilangan peroksida, titik leleh, kadar karoten dan komposisi asam lemak menggunakan prosedur standar MPOB (MPOB, 2004).

\section{Pengaruh Jumlah Cabai dan Minyak dalam Pembuatan Sambal Cabai Merah}

Sebanyak 50 g cabai merah giling ditumis menggunakan minyak (MSM atau MSMOL) yang divariasikan jumlahnya yaitu 10, 20, 30, 40, dan $50 \mathrm{~g}$. Minyak dipanaskan pada suhu $100^{\circ} \mathrm{C}$, lalu cabai dimasukkan ke dalam minyak dan ditumis selama 5 menit. Produk sambal cabai merah diuji organoleptik terhadap kesukaan kenampakan warna, tekstur (proporsi minyak dan cabai), aroma dan penerimaan keseluruhan terhadap 25 orang panelis agak terlatih.

\section{Pengaruh Penambahan Garam dan Gula} dalam Pembuatan Sambal Cabai Merah

Sebanyak $50 \mathrm{~g}$ cabai merah giling dicampurkan dengan 40 g MGK dan dipanaskan pada suhu $100{ }^{\circ} \mathrm{C}$ selama 5 menit. Campuran ditambahkan garam $(0,2$, dan $4 \%$ terhadap berat cabai) dan gula $(0,2$, dan $4 \%$ terhadap berat cabai). Produk yang dihasilkan diuji organoleptik terhadap kesukaan rasa sambal cabai merah pada 25 orang panelis agak terlatih.

\section{Pengaruh Suhu dan Waktu dalam Pembuatan Sambal Cabai Merah}

Suhu dan waktu pemasakan cabai merah dilakukan menggunakan 2 cara yaitu cara pertama dengan pemanasan terpisah. MSM dipanaskan hingga mencapai suhu tertentu, lalu cabai dimasukkan dan dimasak sesuai waktu yang ditentukan. Cara kedua dengan pemanasan langsung. Cabai dan MSM dicampur bersamaan lalu dipanaskan pada suhu dan waktu yang ditentukan. Suhu yang divariasikan adalah 75, 100, 125, 150 dan $175^{\circ} \mathrm{C}$ dengan waktu selama 5 dan 10 menit. Produk yang dihasilkan diuji kadar karoten dan kadar air pada minyak (minyak dipisahkan dari cabai dengan penyaringan) menggunakan prosedur standar MPOB (MPOB, 2004).

\section{Pengaruh Jenis Minyak dalam Pembuatan Sambal Cabai Merah}

Sebanyak $50 \mathrm{~g}$ minyak ditumis menggunakan 40 g minyak (MGK, MSM dan MSMOL), ke dalam campuran juga ditambahkan gula dan garam sesuai dengan jumlah optimum pada kondisi yang diperoleh dari kegiatan sebelumnya. Produk yang dihasilkan diuji parameter kimia minyak dan uji organoleptik sambal. Uji kimia minyak (minyak dipisahkan dari cabai dengan penyaringan) dianalisa kadar ALB, bilangan peroksida, dan kadar karoten. Uji organoleptik sambal cabai merah dilakukan terhadap kenampakan warna, tekstur, aroma, rasa dan penerimaan keseluruhan.

\section{Uji Ketahanan Penyimpanan Sambal Cabai Merah}

Sebanyak 50 g cabai merah giling ditumis menggunakan 40 g MGK, MSM, dan MSMOL pada suhu dan waktu optimum yang diperoleh pada kegiatan sebelumnya. Sambal cabai merah didinginkan lalu dimasukkan ke dalam botol plastik bertutup. Uji ketahanan sambal cabai merah ditentukan pada suhu 28-32 ${ }^{\circ} \mathrm{C}$ dan $20-24{ }^{\circ} \mathrm{C}$ selama penyimpanan 1 bulan. Parameter yang diuji pada minyak adalah kadar ALB, bilangan peroksida, dan kadar karoten menggunakan metode standar MPOB (MPOB, 2004).

\section{Uji Organoleptik}

Uji organoleptik dilakukan oleh 25 orang panelis agak terlatih terhadap penerimaan kesukaan produk sambal cabai merah. Skala uji dibagi menjadi 5 yaitu tidak suka (1), kurang suka (2), cukup suka (3), suka (4) dan sangat suka (5).

\section{HASIL DAN PEMBAHASAN}

\author{
Mutu dan Karakteristik Minyak untuk \\ Pembuatan Sambal Cabai Merah \\ Mutu minyak sawit merah (MSM), \\ MSM fraksi olein (MSMOL) dan minyak
}


Jurnal Teknologi Pertanian Vol. 19 No. 2 [Agustus 2018] 95-106

Penggunaan Minyak Sawit Merah dalam Pembuatan Sambal [Hasibuan dkk]

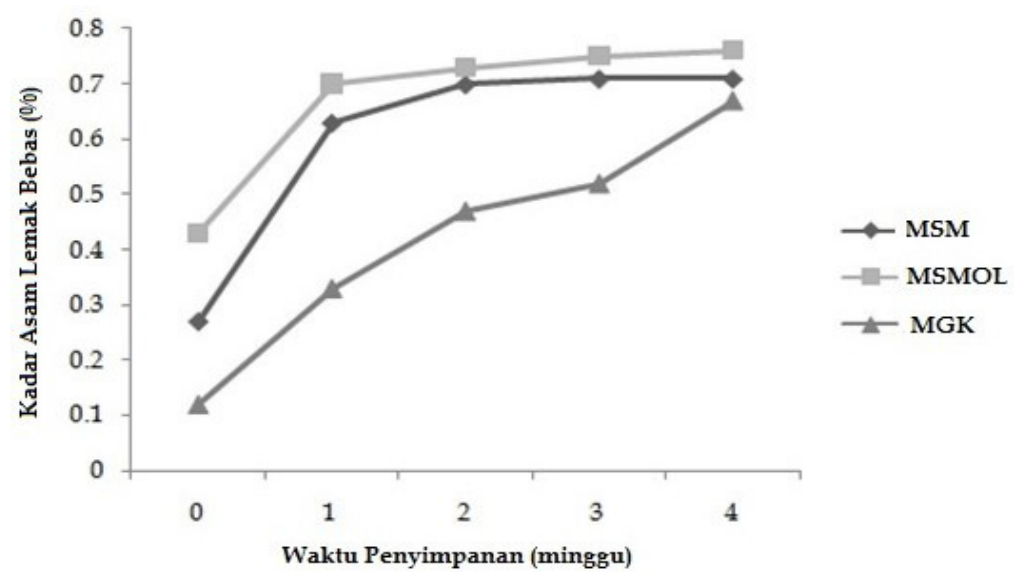

Gambar 1. Kadar asam lemak bebas pada minyak sambal cabai merah selama penyimpanan pada suhu $28-32{ }^{\circ} \mathrm{C}$

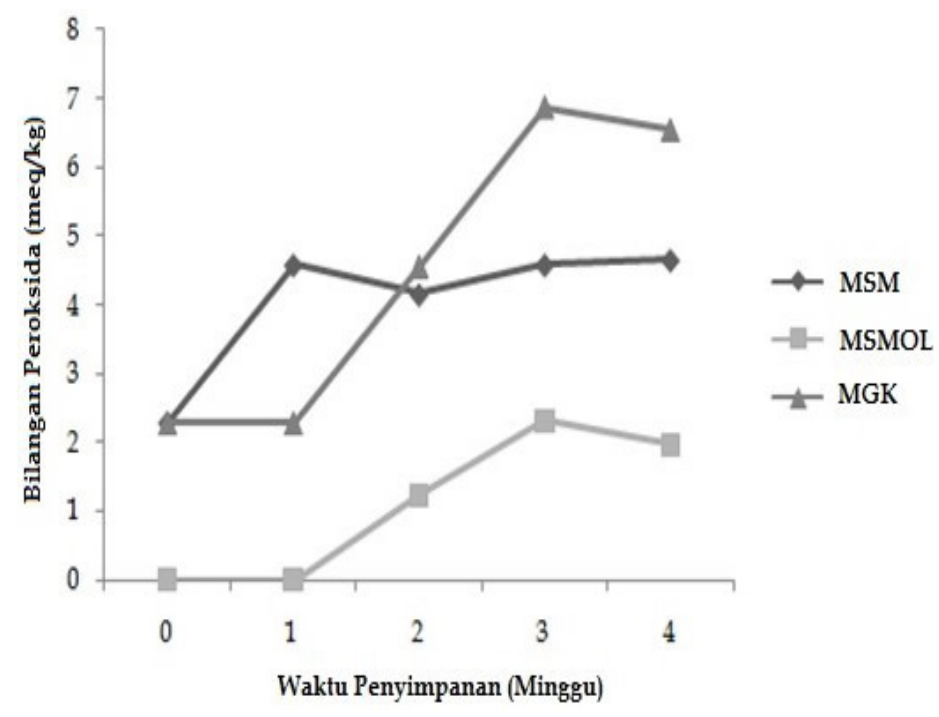

Gambar 2. Bilangan peroksida pada minyak sambal cabai merah selama penyimpanan pada suhu $28-32{ }^{\circ} \mathrm{C}$

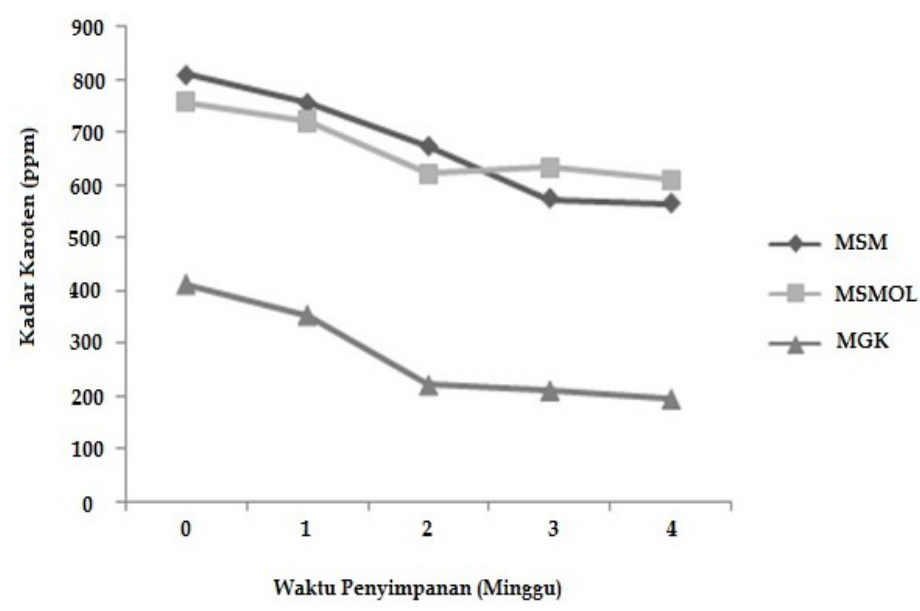

Gambar 3. Kadar karoten pada minyak sambal cabai merah selama penyimpanan pada suhu $28-32{ }^{\circ} \mathrm{C}$ 
Tabel 1. Mutu MSM, MSMOL, dan MGK

\begin{tabular}{lcccc}
\hline \multicolumn{1}{c}{ Sampel } & Air (\%) & ALB (\%) & $\begin{array}{c}\text { Bilangan peroksida } \\
\text { (meq/ kg) }\end{array}$ & Karoten (ppm) \\
\hline MSM & $0.24 \pm 0.07$ & $0.22 \pm 0.03$ & 0 & $519 \pm 4.24$ \\
MSMOL & $0.15 \pm 0.03$ & $0.38 \pm 0.05$ & 0 & $450 \pm 6.27$ \\
MGK & $0.02 \pm 0.01$ & $0.08 \pm 0.01$ & 0 & $3 \pm 0.56$ \\
\hline
\end{tabular}

Keterangan: MSM=minyak sawit merah, MSMOL=minyak sawit merah fraksi olein, MGK=minyak goreng komersial, $\mathrm{ALB}=$ asam lemak bebas

Tabel 3. Penerimaan sambal cabai merah menggunakan minyak sawit merah

\begin{tabular}{ccccc}
\hline \multirow{2}{*}{ Sampel } & \multicolumn{4}{c}{ Parameter } \\
\cline { 2 - 5 } & $\begin{array}{c}\text { Kenampakan } \\
\text { Warna }\end{array}$ & $\begin{array}{c}\text { Tekstur } \\
\text { (proporsi minyak:cabai) }\end{array}$ & Aroma & $\begin{array}{c}\text { Penerimaan } \\
\text { keseluruhan }\end{array}$ \\
\hline MSM:cabai merah $(g / g)$ & & & 1.00 & 1.39 \\
MSM 1 (10:50) & 1.67 & 1.50 & 2.67 & 2.11 \\
MSM 2 (20:50) & 2.00 & 1.67 & 3.17 & 3.28 \\
MSM 3 (30:50) & 3.50 & 3.17 & 3.00 & 3.39 \\
MSM 4 (40:50) & 3.67 & 3.50 & 3.17 & 3.28 \\
MSM 5 (50:50) & 3.67 & 3.00 & & \\
MSMOL: cabai merah $(g / g)$ & & & 1.00 & 1.50 \\
MSMOL 1 (10:50) & 2.00 & 1.50 & 2.67 & 2.39 \\
MSMOL 2 (20:50) & 2.83 & 1.67 & 3.17 & 3.00 \\
MSMOL 3(30:50) & 2.67 & 3.17 & 3.00 & 3.17 \\
MSMOL 4 (40:50) & 3.00 & 3.50 & 3.17 & 2.45 \\
MSMOL 5 (50:50) & 1.17 & 3.00 & & \\
\hline
\end{tabular}

Keterangan: MSM=minyak sawit merah, MSMOL=minyak sawit merah fraksi olein, tingkat skala kesukaan 1-5 (tidak suka (1), kurang suka (2), cukup suka (3), suka (4) dan sangat suka (5))

Tabel 4. Penerimaan kesukaan sambal cabai dengan penambahan garam dan gula

\begin{tabular}{lccccccccc}
\hline \multirow{2}{*}{ Parameter } & \multicolumn{7}{c}{ Garam dan Gula (\%/ \% terhadap berat cabai) } \\
\cline { 2 - 9 } & $\mathbf{0 : 0}$ & $\mathbf{2 : 0}$ & $\mathbf{4 : 0}$ & $\mathbf{0 : 2}$ & $\mathbf{2 : 2}$ & $\mathbf{4 : 2}$ & $\mathbf{0 : 4}$ & $\mathbf{2 : 4}$ & $\mathbf{4 : 4}$ \\
\hline Penerimaan rasa & 1.25 & 2.33 & 2.33 & 1.75 & 2.75 & 3.17 & 1.75 & 4.08 & 3.58 \\
\hline $\begin{array}{l}\text { Keterangan: tingkat skala kesukaan 1-5 (tidak suka (1), kurang suka (2), cukup suka (3), suka (4) dan sangat } \\
\text { suka (5)) }\end{array}$
\end{tabular}

Tabel 6. Mutu minyak sambal cabai merah

\begin{tabular}{lccc}
\hline Nama Sampel & ALB (\%) & Bilangan peroksida (meq/kg) & Karoten (ppm) \\
\hline MSM & $0.27 \pm 0.03$ & $2.29 \pm 0.6$ & $810 \pm 8.7$ \\
MSMOL & $0.43 \pm 0.03$ & $0.00 \pm 0.0$ & $758 \pm 6.5$ \\
MGK & $0.12 \pm 0.01$ & $2.29 \pm 0.9$ & $413 \pm 5.1$ \\
\hline
\end{tabular}

Keterangan: MSM=minyak sawit merah, MSMOL=minyak sawit merah fraksi olein, MGK=minyak goreng komersial, $\mathrm{ALB}=$ asam lemak bebas 


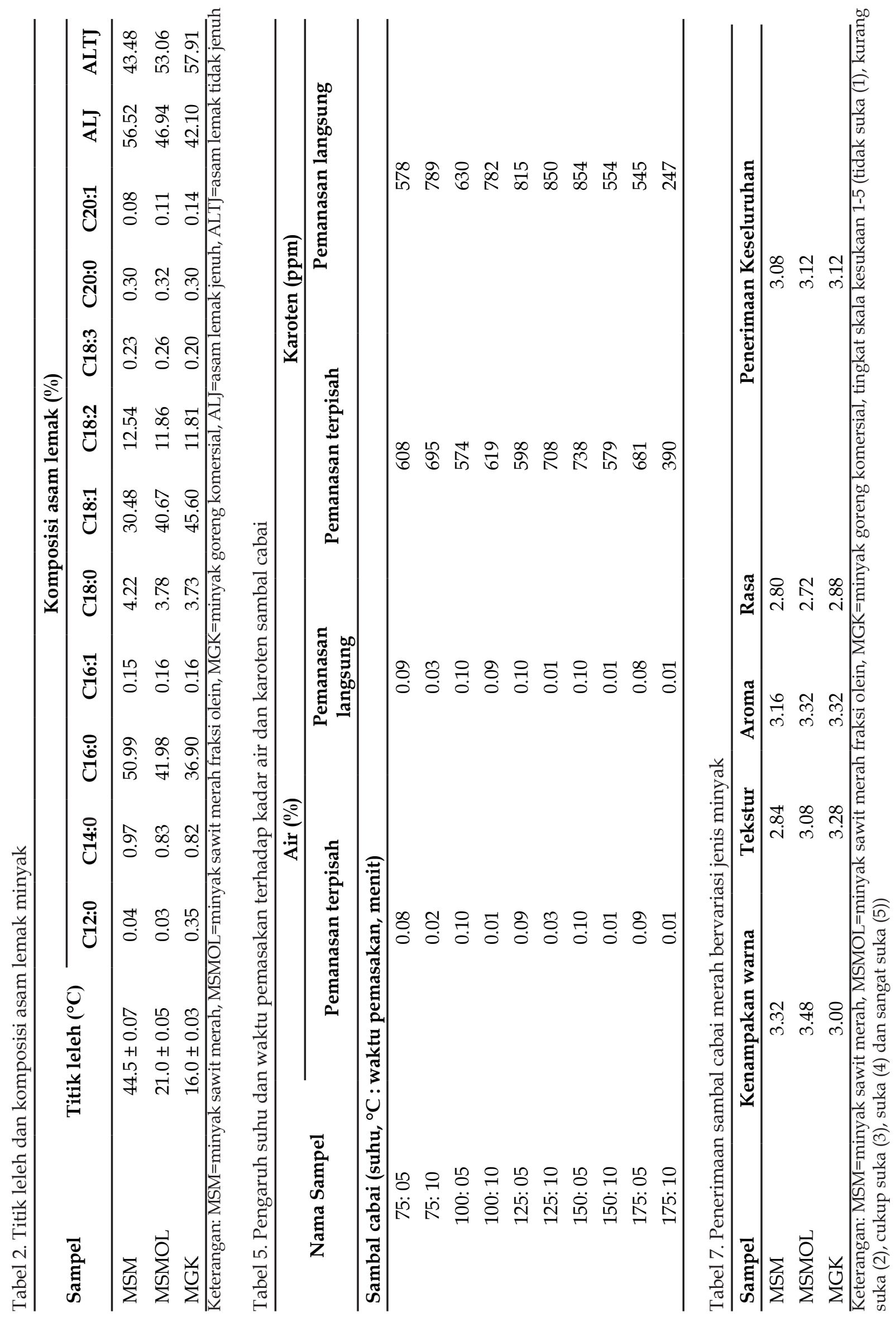


goreng komersial (MGK) meliputi kadar air, bilangan peroksida, dan kadar karoten disajikan pada Tabel 1. MSM dan MSMOL memiliki kadar air tinggi dikarenakan pada proses pembuatannya minyak sawit mentah (crude palm oil/CPO) dinetralisasi menggunakan basa dengan tujuan untuk menurunkan asam lemak bebas (ALB), dan dicuci dengan air untuk menghilangkan sisa basa dan sabun. Di samping itu, proses deodorisasi tidak dilakukan pada suhu tinggi agar senyawa karoten tidak terdegradasi (hanya pada suhu $100{ }^{\circ} \mathrm{C}$ selama 1 jam), sehingga tidak semua air menguap. MSMOL memiliki kadar ALB tinggi diikuti oleh MSM dan MGK. Sementara itu, ketiga jenis minyak belum teroksidasi (nilai PV sebesar 0). Berdasarkan SNI 7709:2012, kadar ALB dan bilangan peroksida maksimum dalam minyak goreng sebesar $0.3 \%$ dan $10 \mathrm{meq} / \mathrm{kg}$. MSM memiliki kadar karoten tinggi diikuti MSMOL dan MGK. MGK memiliki karoten rendah karena selama proses pembuatannya dilakukan bleaching menggunakan tanah pemucat (bleaching earth) dan di deodorisasi pada suhu tinggi $\left(250-265^{\circ} \mathrm{C}\right)$.

Titik leleh dan komposisi asam lemak ketiga jenis minyak disajikan pada Tabel 2. MSM memiliki titik leleh tinggi dibandingkan MSMOL dan MGK. Titik leleh dipengaruhi oleh komposisi asam lemak pada minyak. Titik leleh yang tinggi dikarenakan asam lemak jenuh yang dikandung minyak juga tinggi. MSM memiliki asam palmitat yang tinggi dibandingkan MSMOL dan MGK sebaliknya MGK memiliki asam oleat tinggi. MSM memiliki jumlah asam lemak jenuh tinggi sedangkan MGK memiliki jumlah asam lemak tidak jenuhnya tinggi.

\section{Pengaruh Jumlah Cabai dan Minyak terhadap Penerimaan Sambal Cabai Merah}

Penerimaan sambal cabai merah yang ditumis dengan MSM dan MSMOL terhadap kenampakan warna, tekstur (proporsi minyak dan cabai) dan aroma disajikan pada Tabel 3. Perbandingan antara cabai dan MSM atau MSMOL yang disukai oleh panelis adalah pada rasio $50 \mathrm{~g}$ cabai dan 40 g minyak. Pada rasio minyak di bawah 40 g cabai kurang terselimuti oleh minyak, sedangkan diatasnya proporsi minyak berlebihan. Hasil rasio antara cabai dan minyak ini akan digunakan untuk kegiatan selanjutnya.
Pengaruh Penambahan Gula dan Garam Terhadap Penerimaan Sambal Cabai Merah

Penambahan gula dan garam dalam pembuatan sambal cabai merah sangat berpengaruh terhadap rasa dari sambal tersebut. Kegiatan ini dilakukan dengan menggunakan MGK (sebagai kontrol) karena tidak berbau dan berwarna seperti MSM atau MSMOL, sehingga diharapkan tidak mempengaruhi penilaian panelis terhadap rasa manis atau asin sambal cabai. Perbandingan jumlah antara garam dan gula yang tidak sesuai dapat menghasilkan rasa sambal yang tidak enak untuk dikonsumsi. Tabel 4 menunjukkan penerimaan kesukaan sambal cabai terhadap penambahan garam dan gula. Sambal cabai yang menggunakan garam atau gula saja kurang disukai oleh panelis. Perbandingan antara garam dan gula yang paling disukai (nilai 4.08 ) adalah $2 \%$ dan $4 \%$ dari berat cabai dalam rasio cabai dan minyak (50:40 g/g).

\section{Pengaruh Suhu dan Waktu Terhadap Kualitas Sambal Cabai Merah}

Tabel 5 menunjukkan suhu dan waktu memasak sambal cabai merah berpengaruh terhadap kadar air dan karoten sambal cabai merah yang ditumis menggunakan MSM. Memasak dengan cara pemanasan terpisah dan pemanasan langsung pada setiap suhu dan waktu pemasakan memberikan kadar air yang relatif tidak berbeda (kadar air pada setiap suhu selama 5 menit sebesar 0.08-0.10\% dan 10 menit sebesar 0.01-0.03\%). Kadar air sangat penting dalam menentukan daya awet dari bahan makanan karena mempengaruhi sifat fisik, kimia, perubahan mikrobiologi, dan perubahan enzimatis. Kandungan air yang tinggi dapat menyebabkan daya tahan bahan atau produk rendah (IFT, 1975; Winarno, 2004; Memon et al., 2018).

Kadar karoten pada minyak sambal cenderung lebih tinggi dibandingkan pada MSM seperti yang terlihat pada Tabel 1, diduga cabai merah mengandung senyawa berwarna dan pada panjang gelombang 446 nm terbaca sebagai karoten. Ekstrak cabai memberikan absorbansi dan apabila dihitung sebagai karoten kadarnya sebesar 15459 ppm). Cabai mengandung senyawa capsaicin yang merupakan senyawa alkaloid dan memberikan rasa dan aroma pedas pada cabai (Sumpena, 2013; Renate et al., 2014). Selain itu, Ashari (2006) melaporkan bahwa cabai juga mengandung vitamin A sebesar 470 IU. 
Peningkatan suhu pemasakan dari 75-150 ${ }^{\circ} \mathrm{C}$ cenderung meningkatkan kadar karoten pada minyak. Pemasakan pada suhu $150^{\circ} \mathrm{C}$ selama 5 menit diperoleh minyak sambal cabai mengandung kadar karoten sebesar 738 ppm (pemanasan terpisah) dan 854 ppm (pemanasan langsung) namun menurun dengan meningkatnya waktu (10 menit) dan suhu pemasakan $\left(>150^{\circ} \mathrm{C}\right)$. Peningkatan ini diduga disebabkan oleh MSM yang dipanaskan mampu melarutkan senyawa karoten yang dikandung cabai merah sehingga bercampur dengan karoten yang dikandung MSM. Namun demikian, penurunan kadar karoten cukup drastis terjadi dengan kenaikan suhu di atas $150^{\circ} \mathrm{C}$, hal ini diduga karena karoten terdegradasi dalam jumlah yang besar. Hasibuan et al. (2013) juga melaporkan bahwa pemanasan minyak berkadar karoten 30-50 ppm dan 75-100 ppm pada $180{ }^{\circ} \mathrm{C}$ selama 30 menit menurunkan kadar karoten sebesar $35-40 \%$ dan $40-50 \%$. Peningkatan pemanasan hingga 120 menit menyebabkan penurunan kadar karoten menjadi sebesar $60-81 \%$ dan $87 \%$. Senyawa karoten mudah terdegradasi oleh panas, cahaya dan asam (Liew et al., 1994; Fauzi dan Sarmidi, 2010; Ayu et al., 2016; Soukoulis et al., 2017; Calligaris et al., 2018; Kong et al., 2018; ).

\section{Pengaruh Jenis Minyak terhadap Mutu dan Penerimaan Sambal Cabai Merah}

Tabel 6 menunjukkan kadar ALB, bilangan peroksida dan kadar karoten sambal cabai merah yang ditumis menggunakan MSM, MSMOL dan MGK (sebagai pembanding). Ketiga jenis minyak tersebut mengalami kenaikan kadar ALB setelah digunakan untuk memasak cabai merah menjadi sambal. Sambal cabai merah menggunakan MSMOL memiliki kadar ALB tertinggi dibandingkan MSM dan MGK yang disebabkan oleh bahan baku awalnya sudah memiliki ALB tinggi (Tabel 1). Adanya pemanasan pada suhu $150{ }^{\circ} \mathrm{C}$, ALB terpicu meningkat dikarenakan adanya air sehingga reaksi hidrolisis dapat terjadi. ALB dalam minyak tidak dikehendaki karena kenaikan ALB menghasilkan rasa dan bau yang tidak disukai.

Minyak yang terkandung pada sambal cabai merah menggunakan MSMOL tidak memiliki bilangan peroksida, sedangkan MSM dan MGK terjadi peningkatan bilangan peroksida dari 0 menjadi $2.29 \mathrm{meq} / \mathrm{kg}$. Nilai ini masih memenuhi standar pada minyak goreng yaitu maksimum $10 \mathrm{meq} / \mathrm{kg}$ (SNI
7709:2012). Bahan makanan yang mengandung lemak dengan bilangan peroksida tinggi akan mempercepat ketengikan, dan lemak dengan bilangan peroksida lebih besar dari 100 dapat meracuni tubuh (Nurhasanawati $e t$ al., 2015; Cebi et al., 2017; Haman et al., 2017; ).

Kadar karoten pada minyak yang terkandung sambal cabai merah menggunakan MSM, MSMOL dan MGK cenderung meningkat dibandingkan bahan bakunya. Seperti telah dijelaskan sebelumnya, bahwa peningkatan ini terjadi disebabkan oleh cabai mengandung capsaicin dan vitamin A yang tinggi. Hal ini juga dibuktikan dengan minyak pada sambal cabai merah yang menggunakan MGK mengandung karoten sebesar 413 ppm padahal MGK (bahan baku awal) hanya mengandung karoten sebesar 3 ppm (Tabel 1).

\section{Uji Organoleptik Sambal Cabai Merah}

Penerimaan sambal cabai merah menggunakan MSM, MSMOL dan MGK terhadap kenampakan warna, tekstur, aroma, rasa dan peneriman secara keseluruhan disajikan pada Tabel 7. Penerimaan sambal dengan MSM, MSMOI dan MGK memiliki nilai yang relatif sama yaitu pada kisaran cukup suka (3.0). Penerimaan tekstur sambal cabai yang ditumis menggunakan MSM relatif rendah (2.84) dikarenakan pada suhu ruangan sambal cabai yang telah ditumis menggunakan MSM berbentuk padat karena titik leleh MSM tinggi (Tabel 2).

\section{Uji Ketahanan Penyimpanan Sambal Cabai Merah}

Minyak pada sambal cabai merah yang disimpan pada suhu $28-30{ }^{\circ} \mathrm{C}$ selama 1 bulan menunjukkan terjadinya peningkatan ALB (Gambar 1) dan bilangan peroksida (Gambar 2), namun penurunan kadar karoten (Gambar 3). Kadar ALB dan bilangan peroksida minyak sambal cabai merah menggunakan MGK cenderung meningkat setiap minggunya sedangkan MSM dan MSMOL meningkat pada minggu pertama namun cenderung lambat dengan meningkatnya waktu penyimpanan. Kadar karoten minyak pada sambal cabai merah menggunakan MGK juga menurun secara drastis dengan peningkatan waktu penyimpanan. Sementara itu, kadar karoten pada minyak sambal cabai merah yang menggunakan MSMOL relatif lebih rendah penurunannya. 
Selama penyimpanan, minyak mengalami perubahan fisika-kimia yang dapat disebabkan oleh proses hidrolisis maupun oksidasi. Peningkatan bilangan peroksida terjadi karena adanya peningkatan kadar peroksida pada minyak yang dapat disebabkan oleh reaksi oksidasi yang terjadi secara terus menerus. Oleh karena waktu penyimpanan yang semakin lama, maka reaksi oksidasi terus berlangsung sehingga jumlah peroksida semakin meningkat. Proses oksidasi pada minyak dapat berlangsung bila terjadi kontak antara sejumlah oksigen dengan minyak atau lemak. Gejala timbulnya ketengikan oleh proses oksidasi lemak pada tahap permulaan ditandai dengan timbulnya flavor, flatness atau oiliness, yang disusul dengan perubahan rasa dan aroma yang terdapat secara alamiah. Selanjutnya minyak tersebut berubah menjadi bau yang tidak disukai dengan bau apek. Jika ketengikan lemak telah mencapai tahap terakhir, maka lemak biasanya berbau tengik dan terasa getir. Hal ini disebabkan oleh terjadinya reaksi oksidasi sekunder dari hasil dekomposisi peroksida (Nurhasnawati et al., 2015; Allen et al., 2018; Gamaralalage et al., 2018; Norizzah et al., 2018; Wan et al., 2018).

Pengamatan yang dilakukan secara visual dan penciuman menunjukkan bahwa selama penyimpanan selama 1 bulan terjadi pertumbuhan jamur dan ketengikan sambal cabai merah. Pertumbuhan jamur di ruangan bersuhu $20-24{ }^{\circ} \mathrm{C}$ relatif lebih lambat daripada di ruangan bersuhu $28-32{ }^{\circ} \mathrm{C}$, begitupula untuk aroma ketengikannnya. Selain itu, semakin lama waktu penyimpanan maka semakin banyak jamur yang berkembang dan aroma tengik juga semakin meningkat. Mizana et al., (2016) juga melaporkan bahwa pertumbuhan jamur pada roti dapat terjadi lebih cepat dan lebih banyak pada suhu $25-28{ }^{\circ} \mathrm{C}$ dibandingkan pada suhu $10-15^{\circ} \mathrm{C}$. Muchtar et al. (2011) juga melaporkan bahwa pertumbuhan jamur pada gambir lebih sedikit yang disimpan pada suhu $25-29{ }^{\circ} \mathrm{C}$ dibandingkan $24-26^{\circ} \mathrm{C}$. Hal ini disebabkan oleh hubungan temperatur dengan kelembaban relatif karena semakin tinggi suhu maka kelembaban relatif semakin rendah dan sebaliknya (Mizana et al., 2016). Pertumbuhan jamur pada produk sambal dapat disebabkan oleh kandungan karbohidrat pada cabai serta adanya penambahan gula yang merupakan sumber nutrisi bagi organisme. Adanya jamur juga dapat mempengaruhi aroma pada produk.
Suhu penyimpanan akan mempengaruhi reaksi kimiawi dan reaksi enzimatis pada mikroba yang berpengaruh pada pertumbuhan mikroba (Nani, 2010; Wang et al., 2018). Sambal cabai yang menggunakan MSMOL cenderung relatif lebih tahan terhadap pertumbuhan jamur dan ketengikan selama 2 minggu kecuali pada suhu $28-30{ }^{\circ} \mathrm{C}$ jamur mulai terbentuk. Sementara sambal menggunakan MSM pada kedua suhu penyimpanan waktunya tidak sampai 1 minggu sedangkan MGK pada suhu $28-30{ }^{\circ} \mathrm{C}$ ketahanan sambal tidak sampai 2 minggu. Pengujian jenis cemaran mikroba atau bakteri perlu dilakukan agar diketahui jenisnya pada produk agar disesuaikan dengan Standar nasional Indonesia bumbu. Mirawati et al. (2013) menambahkan bahwa mikroba dan bakteri pathogen dapat menyebabkan keracunan makanan. Mat Sharif et al. (2017) menambahkan bahwa sambal cabai yang tidak menggunakan bahan pengawet tidak tahan lama dan dapat menggunakan bahan pengawet seperti natrium benzoat.

\section{SIMPULAN}

Minyak sawit merah (MSM) dapat digunakan sebagai bahan pengganti minyak goreng dalam penumisan sambal cabai merah. Rasio antara cabai dan minyak adalah 50 dan 40 (g/g) dengan rasio garam dan gula $2 \%$ dan $4 \%$ dari berat cabai. Proses pemasakan sambal cabai merah yang baik adalah cabai dan minyak dicampurkan secara bersamaan kemudian dipanaskan pada suhu 150 ${ }^{\circ} \mathrm{C}$ selama 5 menit. MSM fraksi olein (MSMOL) merupakan minyak yang memiliki kestabilan terhadap penyimpanan terbaik yaitu relatif tahan selama 2 minggu pada suhu 20$24{ }^{\circ} \mathrm{C}$ dan 1 minggu pada suhu $28-30{ }^{\circ} \mathrm{C}$

\section{DAFTAR PUSTAKA}

Adewuyi, O, A, Abu, J, O, Amuta, E, U, Abu, G, A, Iombor, T, T, Ingbian, E, K. 2014. Knowledge, use and sensory evaluation of red palm oil OGI by caregivers in makurdi, nigeria. African Journal of Food, Agriculture, Nutrition and Development. 14(2):8761-8775 
Jurnal Teknologi Pertanian Vol. 19 No. 2 [Agustus 2018] 95-106

Penggunaan Minyak Sawit Merah dalam Pembuatan Sambal [Hasibuan dkk]

Alex, S. 2012. Usaha Tani Cabai, Kiat Jitu Bertanam Cabai di Segala Musim. Pustaka Baru Press. Jakarta

Allen, K, Hassler, E, Kurniawan, S, Veldkamp, E, Corre, M, D. 2018. Canopy soil of oil palm plantations emits methane and nitrous oxide. Soil Biology and Biochemistry. 122:1-6

Ashari, S. 2006. Holtikultura Aspek Budaya. UIPress. Jakarta

Ayeleso, A, O, Oguntibeju, O, O, Brooks, N, L. 2012. Effects of dietary intake of red palm oil on fatty acid composition and lipid profiles in male wistar rats. African Journal of Biotechnology. 11(33):8275-8279

Ayu, D, F, Andarwulan, N, Hariyadi, P, Purnomo, E, H. 2016. Kinetika fotodegradasi klorofil, tokoferol dan karotenoid dalam minyak sawit merah. Agritech. 36(2):117-127

Calligaris, S, Valoppi, F, Barba, L, Anese, M, Nicoli, M, C. 2018. $\beta$-Carotene degradation kinetics as affected by fat crystal network and solid/liquid ratio. Food Research International. 105:599-604

Calzada, T, R, Qian, M, Strid, A, Neugart, S, Schreiner, M, Pacheco, I, T, GuevaraGonzáleza, R, G. 2018. Effect of UV-B radiation on morphology, phenolic compound production, gene expression, and subsequent drought stress responses in chili pepper (Capsicum annuum L.). Plant Physiology and Biochemistry

Cassiday, L. 2017. Red palm oil. INFORM. 28(2):6-10

Cebi, N, Yilmaz, M, T, Sagdic, O, Yuce, H, Yelboga, E. 2017. Prediction of peroxide value in omega-3 rich microalgae oil by ATR-FTIR spectroscopy combined with chemometrics. Food Chemistry. 225:188-196

Farid, M, Subekti, N, A. 2012. Tinjauan terhadap produksi, konsumsi, distribusi dan dinamika harga cabe di Indonesia. Buletin Ilmiah Litbang Perdagangan. 6(2):211-234

Farkas, J, Cs Mohácsi-Farkas. 2014. Safety of Food and Beverages: Spices and Seasonings. Encyclopedia of Food Safety. 3:324-330

Fauzi, N, A, M, Sarmidi, M, R. 2010. Extraction of heat treated palm oil and their stability on beta-carotene during storage. Journal of Science and Technology. 2(1):45-54
Gamonpilas, C, Pongjaruvat, W, Fuongfuchat, A, Methacanon, P, Seetapan, N, Thamjedsada, N. 2011. Physicochemical and rheological characteristics of commercial chili sauces as thickened by modified starch or modified starch/ xanthan mixture. Journal of Food Engineering. 105(2):233-240

Gamaralalage, D, Sawai, O, Nunoura, T. 2018. Degradation behavior of palm oil mill effluent in Fenton oxidation. Journal of Hazardous Materials.

Haman, N, Romano, A, Asaduzzaman, M, Ferrentino, G, Biasioli, F, Scampicchio, M. 2017. A microcalorimetry study on the oxidation of linoleic acid and the control of rancidity. Talanta. 164:307412

Hasibuan, H, A, Rivani, M, Lubis, A. 2013. Studi sabilitas $\beta$-karoten yang digunakan sebagai bahan fortifikasi minyak goreng kelapa sawit. Warta Pusat Penelitian Kelapa Sawit. 18 (3):91-95

Hasibuan, H, A, Siahaan, D. 2014. Review standar minyak goreng sawit diperkaya karoten terkait fortifikasi vitamin A sebagai revisi SNI 031-3741-2002. Jurnal Standardisasi. 16:65-76

Hin, L, K, Zain, S, M, Abas, M, R, Mohd, M, A. 2008. Classification of chili sauces: multivariate pattern recognition using selected GCMS retention time peaks of chilli sauce samples. The Malaysian Journal of Analytical Sciences. 12(1):210-216

IFT. 1975. Teach-in no. 11: shelf life of foods. Nutrition \& Food Science. 75(3):10-13

Iqbal, S, Z, Asi, M, R, Mehmood, Z, Mumtaz, A, Malik, N. 2017. Survey of aflatoxins and ochratoxin $\mathrm{A}$ in retail market chilies and chili sauce samples. Food Control. 81:218-223

Iqbal, S, Z, Asi, M, R, Zuber, M, Akhtar, J, Saif, M, J. 2013. Natural occurrence of aflatoxins and ochratoxin A in commercial chilli and chilli sauce samples. Food Control. 30(2):621-625

Kim, S, H, Chung, K, R, Yang, H, J, Kwon, D, Y. 2016. Sunchang gochujang (korean red chili paste): the unfolding of authenticity. Journal of Ethnic Foods. 3(3):201-208

Kim, H, J, Chung, S, J, Kim, K, O, Nielsen, B, Ishii, R, O'Mahony, M. 2018. A crosscultural study of acceptability and food pairing for hot sauces. Apetite. 123:306316 
Kong, L, Bhosale, R, Ziegler, G, R. 2018. Encapsulation and stabilization of $\beta$-carotene by amylose inclusion complexes. Food Research International. 105:446-452

Liew, K, Y, Nordin, M, R, Goh, L, S. 1994. Reaction of carotenes in palm oil with acid. JAOCS. 71(3):303-306

Masani, M, Y, A, Izawati, A, M, D, Rasid, O, A, Kadir, G, Parveez, A. 2018. Biotechnology of oil palm: Current status of oil palm genetic transformation. Biocatalysis and Agricultural Biotechnology. 15:335-347

Mat Sharif, Z, Mohd Taib, N, Yusof, M, S, Rahim, M, Z, Mohd Tobi, A, L, Othman, M, S. 2017. A study on shelf life prolonging process of chili soy sauce in Malaysian SME's (small medium enterprise). Mechanical Engineering, Science and Technology International Conference. 203:1-6

Memon, N, Gat, Y, Arya, S, Waghamare, R. 2018. Combined effect of chemical preservative and different doses of irradiation on green onions to enhance shelf life. Journal of the Saudi Society Agricultural Sciences.

Mirawati, M, Djajaningrat, H, Purwanti, A. 2013. Kualitas bakteriologis cabai giling yang dijual di pasar tradisional wilayah pondok gede. Jurnal Ilmu dan Teknologi Ilmu Kesehatan. 1:47-53

Mizana, D, K, Suharti, N, Amir A. 2016. Indentifikasi pertumbuhan jamur Aspergillus Sp pada roti tawar yang dijual di kota Padang berdasarkan suhu dan lama penyimpanan. Jurnal Kesehatan Andalas. 5(2):355-360

MPOB. 2004. MPOB Test Method: A Compendium of Test on Palm Oil Products, Palm Kernel Products, Fatty Acids, Food Related Products and Others. Malaysia

Muchtar, H, Kamsina, Anova, I, T. 2011. Pengaruh kondisi penyimpanan terhadap pertumbuhan jamur pada gambir. Jurnal Dinamika Penelitian Industri. 22(1):36-43

Nani, R. 2010. Mikrobiologi Pangan. Yogyakarta

Nimrotham, C, Songprakorp, R, Thepa, S, Monyakul, V. 2017. Experimental research of drying red chili by two methods: solar drying and low - temperature system drying. Energy Procedia. 138:512-517

Norizzah, Rashid, A, Azimah, N, Kamarulzaman, Zaliha, Omar. 2018. Influence of enzymatic and chemical interesterification on crystallisation properties of refined, bleached and deodourised (RBD) palm oil and RBD palm kernel oil blends. Food Research International. 106:982-991

Nurhasnawati, H, Supriningrum, R, Caesariana, N. 2015. Penetapan kadar asam lemak bebas dan bilangan peroksida pada minyak goreng yang digunakan pedagang gorengan di jl. a.w sjahranie samarinda. Jurnal Ilmiah Manuntung. $1(1): 25-30$

Perdani, C, G, Zakaria, F, R, Prangdimurti, E. 2016. Pemanfaatan minyak sawit mentah sebagai hepatoprotektor pada ibu rumah tangga di dramaga bogor. Jurnal Teknologi Pertanian. 17(2):119-128

Purawisastra, S, Yuniati, H. 2010. Kandungan natrium beberapa jenis sambal kemasan serta uji tingkat penerimaannya. Penelitian Gizi dan Makanan. 33(2):173-179

Rao, B, S, N. 2000. Potential use of red palm oil in combating vitamin A deficiency in india. Food and Nutrition Bulletin. 21(2):202-211

Renate, D, Pratama, F, Yuliati, K, Priyanto, G. 2014. Model kinetika degradasi capsaicin cabai merah giling pada berbagai kondisi suhu penyimpanan. Agritech. 34(3):330-336

Ribeiro, J, A, A, Almeida, E, S, Neto, B, A, D, Abdelnur, P, V, Monteiro, S. 2018. Identification of carotenoid isomers in crude and bleached palm oils by mass spectrometry. LWT. 89:631-637

Ricaurte, L, Carrión, M, H, Molano, M, M, Romero, A, C, Carvajal, M, X, Q. 2018. Physical, thermal and thermodynamical study of high oleic palm oil nanoemulsions. Food Chemistry. 256:62-70

Rice, A, L, Burns, J, B. 2010. Moving from efficacy to effectiveness: red palm oil's role in preventing vitamin A deficiency. J. Am. Coll. Nutr. 29:302S-313S

Samadi, B. 2007. Budidaya Cabai Merah Secara Komersial. Yayasan Pustaka Nusatama. Yogyakarta

Sarina, N, F, Adzahan, N, M, Sobhi, B, Karim, M, S, A, Karim, R. 2010. Formulation and process improvement for chili shrimp paste using sensory evaluation. International Food Research Journal. 17(4): 927-936 
Jurnal Teknologi Pertanian Vol. 19 No. 2 [Agustus 2018] 95-106

Penggunaan Minyak Sawit Merah dalam Pembuatan Sambal [Hasibuan dkk]

SNI. SNI 7709:2012 Minyak goreng sawit. Dilihat 20 Juli 2018. <https://www. scribd.com/doc/157774034/SNI-Migor-Sawit-SNI-No-7709-2012>

Soukoulis, C, Tsevdou, M, Yonekura, L, Cambier, S, Taoukis, P, S, Hoffmann, L. 2017. Does kappa-carrageenan thermoreversible gelation affect $\beta$-carotene oxidative degradation and bioaccessibility in o/w emulsions?. Carbohydrate Polymers. 167:259-269

Sumpena, U. 2013. Penetapan kadar capsaicin beberapa jenis cabe (Capsicum sp) di Indonesia. Mediagro. 9(2):9-16

Suyanti. 2009. Membuat Aneka Olahan Cabai. Penebar Swadaya. Jakarta

Wan, L, Li, L, Jiao, Mao, L, Li, B, Zhang, X. 2018. Effect of barrel temperature and moisture content on the composition and oxidative stability of extruded palm oil in an oil-starch model system. LWT. 98:398-405

Wang, D, Yan, L, M, X, Wang, W, Zou, M, Zhong, j, ding,T, Ye, X, Liu, D. 2018. International Journal of Biological Macromolecules. 119:453-461 